\title{
RETÓRICA REALISTA E DECISÃO JURÍDICA
}

REALISTIC RHETORIC AND LEGAL DECISION

João Maurício Adeodato

\begin{abstract}
Resumo
0 texto objetiva expor as bases de uma retórica realista, sob a perspectiva descritiva de como a decisão jurídica efetivamente ocorre, sem considerações normativas. 0 idealismo retórico de Aristóteles e seu prestígio posterior reduziram a retórica à arte da persuasão, eliminando elementos importantes da sofística, sobretudo no que concerne à decisão jurídica. Conclui-se com uma perspectiva retórica do ativismo judicial na sociedade complexa.
\end{abstract}

Palavras-chave: Etórica. Erística. Linguagem jurídica. Ativismo judicial. Sofística.

\section{Abstract}

The text aims to lay the foundations of a realistic rhetoric, from the descriptive perspective of how the legal decision actually takes place, without normative considerations. Aristotle's rhetorical idealism and its later prestige reduced rhetoric to the art of persuasion, eliminating important elements of sophistry, especially with regard to legal decision. It concludes with a rhetorical perspective of judicial activism in complex societies.

Keywords: Rhetoric. Eristic. Legal language. Judicial activism. Sophistry 


\section{INTRODUÇÃO: RETÓRICA REALISTA COMO MARCO TEÓRICO}

\subsection{TRÊS PRESSUPOSTOS FILOSÓFICOS}

Impressiona como, em todo o mundo ocidental, o estudo da retórica foi extirpado do estudo do direito. Pois a retórica é uma criação de advogados, de juristas, não de literatos, linguistas e poetas, que são aqueles que hoje dela se ocupam e que por isso merecem encômios. Este texto pretende mostrar as bases históricas e filosóficas dessa relação entre retórica e direito, na esperança de que os estudos jurídicos afastem-se da metafísica da verdade e voltem a suas raízes práticas, estratégicas, argumentativas. Para isso, três pressupostos.

Primeiro pressuposto: a perspectiva retórica é empírica.

É útil começar com uma distinção conceitual entre perspectivas empíricas e perspectivas normativas. Não que essa distinção seja indispensável ao estudo da retórica, mas somente porque este texto vai levá-la em consideração, pressupondo que uma retórica realista precisa de um olhar empirista.

Uma teoria empírica dirige-se ao passado e procura descrevê-lo tal como parece àquele que a defende; essa perspectiva não é tão pretensiosa quanto as outras, mas isso não significa que esteja livre de desacordos, sobretudo quanto a sua suposta característica de abster-se de juízos de valor. Uma teoria normativa tem como vetor o futuro, para o qual procura prescrever otimizações, melhorias na visão de seu autor, isto é, quer modificar, dirigir, influenciar o ambiente e a conduta das pessoas. Uma terceira variante, que se pode chamar de escatológica, é aquela que pretende utilizar o passado para descrever o futuro, prever algo que ainda não existe a partir da observação daquilo que aconteceu, descobrir no passado "leis" que lhe permitiriam antecipar o curso dos eventos no futuro. Por esse caminho vai a maioria das perspectivas sobre as "ciências" sociais hoje.

Ora, se é certo que toda retórica estratégica é normativa, já que pretende conformar o meio segundo a perspectiva de quem a defende, uma teoria normativa sobre o direito, que precisaria ser analítica para 
ser legitimamente teórica, situa-se no nível estratégico e passa a ser difícil separá-la da luta política ou de um wishful thinking bem ou mal intencionado. As teorias normativas são perfeitamente legítimas na busca para modificar o mundo, mas precisariam declarar expressamente que são idealistas e, em muitos casos, não o fazem, apresentando-se como estritamente científicas, descritivas, empíricas.

A perspectiva escatológica pretende "descrever o futuro", o que de início configura uma contradictio in terminis, porque o futuro vai ser fruto das opções normativas dominantes da retórica estratégica vitoriosa e não pode ser descrito, posto que não existe. Só se pode dizer como o futuro deve ser, jamais como vai ser. Aqui se vê a influência das ciências descritivas da natureza, a tentativa de um discurso que seria mero receptáculo, observador das modificações causais do ambiente. A retórica analítica procura ser descritiva, sim, porém descritiva do passado da própria retórica, em seus níveis estratégico (que discursos foram e têm sido colocados para constituir a realidade) e material (que discursos vêm predominando nessa constituição e como isso ocorre).

Segundo pressuposto: relativa incompatibilidade entre tipos ideais conceituais e eventos reais.

A retórica realista renuncia a definições que abarquem completamente objetos específicos (pode-se chamá-las "omnicompreensivas") porque não acredita na correspondência entre pensamento e comunicação humanos, de um lado, e eventos reais, de outro. A "faculdade de conhecer", um dos sentidos atribuídos à "razão" humana, enfrenta o mundo real circundante por meio de generalizações linguísticas que se dividem em significantes e significados. Os eventos reais são individuais e, por isso, inapreensíveis por essa razão do ser humano, vez que seu ato de conhecimento implica necessariamente uma abstração dos elementos contingentes que compõem (e individualizam) cada evento real, isto é, uma construção de "gêneros" ou "classes" de indivíduos, os quais, em homenagem a Platão, pode-se chamar de "ideais"; isso sem a conotação

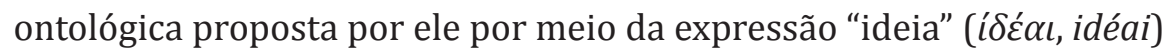
e depois também por Aristóteles com o termo "forma” ( $\varepsilon \ddot{i} \delta \eta$, eídê).

Como jamais há total adequação entre essas ideias humanas significadas e os eventos reais, devido à incompatibilidade entre o pensamento 
humano geral e o mundo dos eventos individuais, propõe-se aqui uma estratégia metodológica (inspirada, dentre outras, naquela dos Idealtypen de Max Weber) de caráter meramente aproximativo, generalizações que reconhecidamente reúnem eventos únicos em tipificações ideais (WEBER, 1985, § 1ํㅡ, I, p. 4 s.). Dessa maneira, todas as distinções conceituais retóricas, como simulação e dissimulação, mentira e ameaça, persuasão e convencimento devem ser entendidas como tipos generalizados sobre eventos únicos em sua efetividade. 0 senso comum levou a chamar esses agrupamentos de eventos de "realidade" (palavra que vem de res, coisa) ambiente no qual eles se entrelaçam, entendidos exatamente como coisas, objetos. Deve-se notar as origens kantianas do pensamento de Weber: a realidade em si mesma (coisa em si) é incognoscível em sua individualidade concreta, é a irracionalidade do individual (HARTMANN, 1946, p. 234 s.).

Terceiro pressuposto: antropologia não-ontológica e linguagem humana.

Com base em Arnold Gehlen, Hans Blumenberg sugere dividir todas as escolas filosóficas em dois extensos grupos, segundo a concepção que tenham da humanidade e, sobretudo, de suas relações com a linguagem e o mundo: para os que entendem os seres humanos como "plenos", verdades evidentes sobre conhecimento e ética estão "lá" (no mundo) para ser literalmente "descobertas", o que irá apenas depender de método, isto é, de competência da abordagem, para o que a linguagem nada mais é que um meio; para os filósofos que consideram os seres humanos "carentes" (Mangelwesen), não há acesso a objetos além da linguagem, que é o único ambiente possível, convencional e arbitrariamente construído, e daí mutável, auto-referente, temporário, instável, metafórico (GEHLEN, 1978; BLUMENBERG, 1986).

Gehlen define a humanidade por meio das características específicas da sua linguagem. A antropologia é para ser vista como "o último capítulo da zoologia", vez que outros animais também são capazes de comunicação. Mas a comunicação não-humana que se conhece constitui um prolongamento daquele que se comunica, uma extensão de sua compleição física, do seu corpo, por assim dizer, é como uma parte daquele que a emite; só a comunicação humana é linguagem, e "linguagem" significa basicamente que emissor e mensagem se separam, esta ganha uma identidade própria que aquele não consegue controlar. Tais dados biológicos levam 
a essa característica antropológica importante: os seres humanos não têm um ambiente natural, não porque sejam superiores e se adaptem a qualquer meio, mas porque seu único ambiente é a linguagem, a qual levam consigo e os obriga a construir seu próprio mundo, sua própria representação como indivíduos e como grupos sociais. É por isso que os seres humanos são seres ainda não formados, "incompletos" (unfertige Wesen). Em compensação, porque carregam seu ambiente consigo, e não apenas sua casa, como os caracóis, os seres humanos literalmente criam seu mundo e um excesso de estímulos (Reizüberflut) para suas reações imprevisíveis. Essas reações ilimitadas - que podem ser chamadas de "liberdade" ou "livre arbítrio" - decorrem da "pobreza de instintos" (Instinktarmut) que caracteriza a espécie.

\subsection{TRES TESES}

A retórica realista baseia-se em três teses básicas, todas pensadas em oposição a teses dominantes na cultura ocidental contemporânea no que diz respeito à retórica; inspiradas no filósofo cético helenista Sextus Empiricus, cujas obras sempre têm por títulos "contra” (adversus) as diferentes ciências que ele quer combater, são denominadas "contra os filósofos ontológicos", "contra os retóricos aristotélicos" e "contra os filósofos ontológicos e os retóricos aristotélicos".

A primeira tese, "contra os filósofos ontológicos", assim se expressa: a retórica não é a arte falaz e enganadora a que por vezes é preconceituosamente reduzida pelos ontológicos (HEGEL, 2000) e até por céticos como o próprio Sextus Empiricus (2013, p. 15 s.), e tampouco consiste somente de mentiras e ornamentos para enredar os incautos, ingênuos ou simplesmente ignorantes - ainda que o estudo dessas estratégias faça parte importante da retórica. Ela também se ocupa, por exemplo, dos discursos que apelam à verdade e à justiça, à persuasão sincera e à igualdade, assim como à autoridade, todas estratégias retóricas.

Desse modo, como queria Aristóteles, a retórica também inclui o estudo de caminhos (ófós, odos) pautados por exigências de sinceridade e consenso. Ele chegou a essa conclusão ao reunir necessariamente retórica e virtude moral, ensinando que o caráter ( $\varepsilon^{\theta} \theta \circ$, , $\dot{\theta} 0 \varsigma$, ethos) deve 


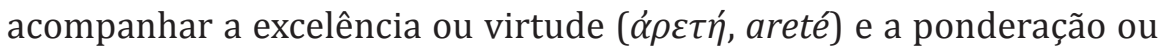
prudência ( $\varphi \rho o ́ v \eta \sigma \iota \varsigma$, phrónesis). A retórica realista, contra os filósofos ontológicos, aceita que a retórica é também o campo da persuasão sincera e da "boa" ética, mas essa é uma relação contingente, pois a retórica pode ser utilizada para quaisquer fins, como queria a sofística. A controvérsia atesta o problema dessa relação milenar entre a retórica e a "boa" ética.

A segunda tese proposta aqui, "contra os retóricos aristotélicos", defende que a persuasão pode ser a via retórica mais importante, por sua eficácia e permanência no tempo, até por sua dignidade ética, mas não é absolutamente a única, pois um estudo realista da retórica precisa se ocupar também de outras vias pelas quais um orador consegue fazer prevalecer seu discurso. Essa tese é importante, sobretudo, para o filósofo retórico preocupado com o direito, pois é no mínimo ingênua ou idealista a perspectiva normativa de reduzir a argumentação dos juristas à persuasão. Retomando a tradição siciliana e sofística original, definir as outras estratégias, erísticas, constitui um dos objetivos da retórica realista. Mas reduzir a retórica aos argumentos sofísticos, como o fazem as ontologias, é o erro do outro lado que a primeira tese procura combater.

A terceira tese, "contra os filósofos ontológicos e os retóricos aristotélicos", é a seguinte: retórica é filosofia, ainda que não investigue a verdade, que considera inatingível. "Verdade" é aqui entendida como um enunciado de aceitação obrigatória, cogente. Sim, porque a filosofia ontológica firmou-se de tal maneira na história do pensamento ocidental que os próprios retóricos passaram a considerar que sua tarefa não fazia parte de uma explicação filosófica do mundo, uma maneira de percebê-lo, de agir nele. Por isso mesmo, tal equívoco tem sido o mais difícil de ser percebido.

Da Antiguidade a nossos dias a visão dominante, tanto da parte dos filósofos ontológicos quanto dos próprios retóricos (BALLWEG, 1982), é que a retórica se separa da filosofia nos primórdios do pensamento grego. Diferentemente, porém, a separação parece ter ocorrido dentro da própria filosofia, a qual já se encontrava solidificada, entre perspectivas retóricas e ontológicas. Não se pense, contudo, que a apropriação da filosofia pelas ontologias, ainda que claramente majoritária, tenha sido foi unânime. Muitos retóricos, de sofistas como Isócrates a céticos 
como Sextus Empiricus, viam a si mesmos e eram vistos como filósofos. Observe-se a etimologia mesma da palavra "filosofia": amor (filo) à sabedoria (sofia) e não à verdade ( $\alpha \dot{\lambda} \eta \dot{\theta} \theta \varepsilon \iota \alpha$, alétheia). E a retórica certamente sempre foi tida como uma forma de sabedoria.

Esse sucesso das ontologias na defesa da verdade como "não-esquecimento", "des-coberta" de um mundo objetivo tem profundas e variadas explicações, que podem ser rasteadas, tais como a necessidade atávica por segurança, de um ponto de vista antropológico; o desejo de controle das diversidades éticas por parte dos bem sucedidos monoteísmos, de uma perspectiva histórica e política; e os sucessos da ciência no domínio de uma natureza hostil, no que diz respeito à técnica, dentre outras.

Mas a filosofia retórica entende que a realidade é criada, constituída, conformada pelo relato vencedor, a retórica material. 0 relato vencedor não é o consenso, muito menos o consenso "racional" defendido por tantos filósofos, nem tampouco envolve necessariamente luta ou competição, pois pode ser obtido por muitos outros meios, como persuasão, sinceridade e solidariedade, nos termos da primeira e da segunda teses acima. A retórica material não quer dizer apenas que o conhecimento do mundo é condicionado pelo aparato cognoscitivo do ser humano, como sugeriu Kant, ou mesmo intermediado pela linguagem, como quer a linguística convencional. Significa dizer que a própria realidade é retórica, pois todo pensamento e toda percepção humanos se dão na e pela linguagem. A retórica material compõe a relação do ser humano com o meio ambiente, forma-se do conjunto de relatos sobre o mundo que constitui a própria existência humana e seu entorno. A pergunta mesma sobre alguma "realidade ôntica" por trás da linguagem não tem qualquer sentido, pois o ser humano é linguisticamente fechado em si mesmo, em um universo de signos, sem acesso a qualquer "objeto" para além dessa circunstância.

Isso não implica que a realidade seja subjetiva, pelo menos no sentido de dependente de cada indivíduo, muito pelo contrário. 0 maior ou menor grau de "realidade" de um relato vai exatamente depender dos outros seres humanos, da possibilidade de controles públicos da linguagem. Nesse sentido podem existir demônios, buracos negros, quarks, ego, superego e quaisquer princípios como o da "salvabilidade do crédito tributário", por mais esdrúxulos que sejam. Só que essas regras de 
controle da retórica material são condicionadas, circunstanciais e tanto mais mutáveis e ambíguas quanto mais complexo e diferenciado o meio social. Por isso não se pode dizer que a retórica realista defenda uma arbitrariedade da linguagem ou, no debate jurídico, qualquer forma de "decisionismo". Daí sua defesa veemente da doutrina como fonte importante do direito. A linguagem tem uma função de controle e a exerce reduzindo complexidade, logo, não pode ser errante, ao talante de cada um, precisa apresentar regularidades; mas essas regularidades são muito variáveis, imprevisíveis, construídas para as exigências do momento e dependentes do ambiente em que atuam.

Em outras palavras, a retórica realista recusa as ontologias de objetos evidentes, mas tampouco reduz o objeto ao sujeito, como os filósofos subjetivistas; ela faz ambos produto da linguagem, que o sujeito não domina, pois até mesmo o pensamento de cada indivíduo é constituído no controle público da linguagem. Qualquer sucessão de eventos somente se torna um "fato" por conta do relato vencedor dentre os participantes do discurso.

A retórica realista também se aparta de qualquer forma de objetivismo, escolástico, jusnaturalista em geral ou científico, pois, ao analisar a questão de que maneira os eventos incognoscíveis são transformados em fatos (relatos sobre supostos eventos), mostra que só se conhecem relatos. Isso em nada muda, mesmo nas chamadas "evidências empíricas", como a existência da lua ou a lei da gravidade. Se apresento cálculos, cuja obediência faz com que a ponte permaneça de pé e que se não forem seguidos a ponte cai, é muito provável que a crença nesses argumentos matemáticos se torne o relato vencedor; do mesmo modo como dizer que Napoleão morreu na Ilha de Santa Helena. Se o sistema jurídico dogmático apresenta um relato, é também provável que este se torne o relato dominante, como ao dizer que a criança deve ficar com a mãe.

Mas nada disso é evidente ou inexorável. Se a retórica estratégica, isto é, interesses, consensos racionais ou não, ameaças, mentiras, engodos, dissimulações, verdades, em suma, todas as formas de narrativas humanas - ou seja, relações retóricas - constituírem a "realidade" dos relatos vencedores em outra direção, as descrições científicas e suas evidências empíricas podem ser completamente derrotadas. 
Essa visão da retórica inspira-se, sobretudo, em Friedrich Nietzsche,

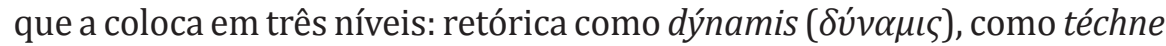

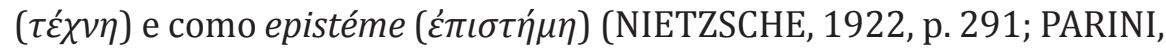
2013, p. 305). Esse é também o caminho escolhido por Ottmar Ballweg (1989). No sentido proposto aqui é assim possível empregar a palavra retórica de três diferentes formas, ou seja, dinâmica (material, existencial), técnica (prática, estratégica) e epistemológica (analítica, científica).

Em seu nível analítico, retórica é filosofia, ainda que não investigue a verdade, que considera uma das estratégias argumentativas.

\section{AS VIAS DA PERSUASÃO NA REDUÇÃO A QUE ARISTÓTELES SUBMETEU A RETÓRICA}

Diferentemente de Platão, Aristóteles se ocupou da retórica. Em seu tempo, a retórica já se tinha desenvolvido muito com o humanismo da sofística e do próprio socratismo, e também se alimentado da concepção de história como um conjunto de relatos exemplares, de pensadores como Tucídides e Heródoto (ambos cerca de 484-430/420 a. C.), bem diferente da concepção da historiografia causal moderna, segunda a qual fatos pretéritos causam eventos futuros. Em outras palavras, quando Aristóteles escreve sua Retórica, a arte dos advogados sicilianos havia sido enriquecida por historicismo, ceticismo e humanismo e assim se tornado filosofia retórica, ao passo que a busca da verdade pela tendência predominantemente científica dos pré-socráticos, aliada à objetividade do bem, perseguida pela ética socrática e platônica, se tornara a filosofia ontológica (ADEODATO, 2012, p. 31 s.).

Em lugar do desprezo genérico votado por Platão ao convencimento e à sedução pelas palavras, Aristóteles parte da observação de que determinados assuntos humanos não admitem juízos de verdade ou falsidade, mas ainda assim são de grande importância. Verdadeiro e falso, pensa ele, continuam constituindo o critério ontológico da filosofia e da ciência, mas, quando não é possível aplicá-lo, é necessário atentar para o terreno da opinião (doxa), do provável, do exemplar, do indício, que constitui o terreno da retórica. Esse ambiente se faz presente em função do tema em discussão, da ignorância ou impaciência do auditório, da escassez de 
tempo para provar todas as premissas, dentre outros motivos comuns nos discursos humanos. Sábio estagirita.

Apesar de convencido da importância da retórica, Aristóteles não se queria confundir com os sofistas, com seu contemporâneo e rival Isócrates, por exemplo. Para isso, procura aliar a retórica à boa ética, à ética do bem, e sua estratégia é reduzir a retórica à persuasão, a qual se caracterizaria por uma espécie de convencimento autêntico.

Difícil definir mais precisamente a persuasão, o que Aristóteles não deixa muito claro. Sabemos que ele a coloca como o objeto da retórica e lhe aporta três vias, quais sejam, o ethos (quem fala), o pathos (como se fala) e o logos (o que se fala). Assim a persuasão inclui elementos como a autoridade do ethos e a sedução do pathos.

Apenas para estabelecer uma comparação, mesmo Hannah Arendt, cuja filosofia é confessadamente inspirada na Grécia Antiga e que já foi acusada de helênica nostálgica (O'SULLIVAN, 1977, p. 15-25), não se filia ao pensamento de Aristóteles e distingue persuasão de autoridade. A persuasão pressupõe igualdade entre os participantes do discurso, a autoridade, diferença. Ethos e auctoritas não são expressões sinônimas, mas certamente a auctoritas romana interpretada por Arendt não se confunde com a persuasão de Aristóteles, apesar de o ethos fazer parte dela. Daí há algo da Retórica de Aristóteles quando Arendt diz que a persuasão legitima pelo conteúdo da mensagem e a autoridade, pelo caráter (ethos) do orador.

Tentando aqui diferenciação que não parece estar em Aristóteles, uma decisão é conseguida por convencimento quando se acredita sinceramente em sua adequação. Em termos mais gerais, no convencimento o comando normativo é aceito pelo seu próprio conteúdo, por aquilo que é transmitido pelo emissor e compreendido pelo receptor da mensagem. Diz mais respeito ao logos do discurso, tal como o entende Aristóteles. A persuasão é muito semelhante, mas é mais frágil do que o convencimento, pois pode implicar uma adesão por conveniência, estratégia, falta de melhor opção, impaciência (o ouvinte pode ser bombardeado por argumentos), em outras palavras, não ser acompanhada da íntima aceitação da mensagem, não ser caracterizada pela sinceridade, sinceridade consciente (observe-se a distinção da língua alemã entre überzeugen, convencer, com 
a raiz mais firme de "testemunhar" e überreden, persuadir, com a raiz de "falar", mais frágil até do que "dizer").

Em Aristóteles, a via persuasão/convencimento acontece quando o discurso do orador efetivamente convence o auditório, que entende o contexto da mensagem, a estruturação dos argumentos, e sinceramente a aceita, comungando da opinião do autor. Aristóteles exclui assim do campo da retórica estratégias argumentativas que faziam parte dela na tradição anterior e que compunham, com variações de ênfase, a erística do discurso.

Na retórica normativa de Aristóteles, ou seja, seu objetivo não é descrever, mas melhorar o discurso humano, o argumento pode ter bases diversas, tais como lugares-comuns, paradigmas, indícios e verossimilhanças, mas jamais engodo ou ameaça de violência, por exemplo. Porém, ao incluir o ethos e o pathos como vias da persuasão, Aristóteles ainda mostra um conceito mais amplo do que o de Hannah Arendt, para quem a persuasão reduz-se à esfera do logos e pressupõe igualdade entre as partes.

Essas três mídias são os caminhos da persuasão na Retórica de Aristóteles e compõem a autoapresentação dos oradores: "a primeira espécie depende do caráter pessoal do orador; a segunda, de provocar no auditório certo estado de espírito; a terceira, da prova, ou aparente prova, fornecida pelas palavras do discurso propriamente dito" (ARISTOTLE, 1990a, v. 8, I, 2, 1356a1-5 e 14-16, p. 595). Vão impregnar toda a terminologia retórica posterior e precisam ser rapidamente explicitadas aqui para que se compreenda o que significa a retórica em Aristóteles.

0 grande problema, comum quando se estudam temas e expressões de tamanha longevidade, é o alto grau de porosidade linguística das palavras; ao longo de tantos anos, há intersecções, diferenciações, traduções ou simplesmente confusões entre os termos.

Etimologicamente, a palavra ethos já parece trazer uma confluência ou evolução de duas palavras gregas, semelhantes, mas distintas: de um

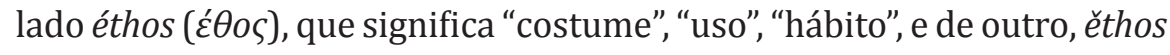
( $\left.\eta^{\prime} \theta \varsigma\right)$ ), "caráter", "forma de pensar". No grego arcaico um termo não se distinguia do outro (PELLEGRIN, 2001, p. 23 s.). Depois da diferenciação, porém, ainda hoje se percebem reflexos desses dois sentidos na palavra ética: um mais social, coletivo e um mais pessoal, individual. 
O ethos designava, assim, um caráter que é resultado do hábito, que se percebe na aparência, nos traços, nas características, no olhar, no porte. Inicialmente, com esse sentido mais físico, é o lugar onde se tem o hábito de viver (habitar), a que se está acostumado, inclusive os animais; aí passa a designar uso, costume, maneiras; uma terceira acepção é a de disposição de caráter, no sentido de inclinação a determinadas atitudes e escolhas humanas, como ter um ethos sonhador, colérico ou melancólico; e um quarto, talvez posterior, refere-se à impressão produzida por um orador nos circunstantes, o que já vai se aproximar do sentido de pathos (LIDDEL e SCOTT, 1996, p. 480 e p. 766; BAILLY, 2000, p. 581 e 894).

A palavra moderna "ética" evolui para significar o conjunto de conhecimentos relacionados ao ethos. Mas não é apenas a doutrina ou disciplina para estudo do ethos, mas também esse próprio ethos, no sentido de designar simultaneamente a metalinguagem (estudo do caráter humano) e a linguagem-objeto (o caráter humano, tal como ele se apresenta). Outros autores preferem denominar essa ética-objeto de "moral", reservando a expressão "filosofia moral" para o conhecimento do objeto (CHAUÍ, 2001, p. 339).

Independentemente das variações dos conceitos, é importante reter que, no plano da metalinguagem, processou-se mais uma diferenciação: "ética" expressa, de um lado, o estudo dos fins que efetivamente guiam a conduta $e$ dos meios que conduzem a esses fins, todos chamados "valores"; de outro, refere-se ao estudo das maneiras de controlar e guiar esses meios e fins. Para dar um exemplo, pela primeira perspectiva, o conhecimento ético mostra que indivíduos inseguros tendem a se aproximar de bajuladores; pela outra, que tanto bajuladores como inseguros devem ser evitados (ou louvados, dependendo da ética). A primeira é a ética descritiva ou analítica, a segunda, a prescritiva ou normativa.

Um dos bons argumentos a favor de considerar a atitude prescritiva como a mais adequada ao conhecimento ético (plano da metalinguagem) é que a abordagem descritiva já estaria a cargo da sociologia, da antropologia, da psicologia e de mais outras ciências (NERI, 2004, p. 27-29).

Pathos, plural páthēe, significa paixão, emoção, sentimento. Fora dos círculos filosóficos, a expressão era usada na linguagem comum e designava qualquer forma de sentimento, porém mais no sentido passivo de 
sofrimento, não como "causa" de ações. Na Retórica de Aristóteles, o pathos está associado ao ouvinte e o ethos ao orador, ainda que essa dissociação de papéis tenha diminuído e até desaparecido em autores posteriores. 0 conceito de pathos passa a reunir os dois sentidos e firma-se para designar qualquer emoção, por meio da qual as pessoas se modificam de tal modo que suas decisões se tornam diferentes do que seriam em um estado emocional habitual. No Renascimento, a retórica do pathos é sistematizada como parte da tópica, reunindo os denominados "argumentos patéticos".

Mas, além de significar esses estados d'alma, pathos designa a expressão ou articulação desses sentimentos e também, o que mais interessa como sentido retórico, indica uma qualidade do discurso, que consiste em despertar no ouvinte os sentimentos que o orador deseja transmitir. Aí está o ponto mais importante: o pathos (retórica estratégica) que desperta o pathos (retórica material) por artes da retórica. Essa transmissibilidade patética do discurso se dá, por exemplo, quando o orador consegue uma disposição contrária àquilo que quer atacar (indignação, deeiinosis, indignatio) ou adesão àquilo que quer defender (compaixão, comiseração, eleeinologia, miseratio).

A importância dada ao pathos pelos oradores parece ter sido muito grande na retórica sofística ao tempo de Aristóteles, pois ele faz críticas aos discursos excessiva ou exclusivamente circunscritos ao pathos. Mesmo assim, em sua ética, apesar de os sentimentos serem considerados irracionais, Aristóteles destaca a importância do pathos e vê uma relação estreita entre pathos e ethos, pois os afetos precisam ser controlados pela virtude do caráter e alcançar um meio-termo desejável racionalmente, prudentemente, a metriopatia entre os extremos maléficos das paixões, pois “...a virtude refere-se a paixões e ações, nas quais o excesso é uma forma de fracasso..." (ARISTOTLE, 1990b, v. 8, II, 5-6, 1106b20-25, p. 352).

Hoje, o adjetivo "patético" ainda mostra a vitória desse controle apolíneo, de Aristóteles a Kant, aparecendo sempre com sentido excessivo, pejorativamente. Isso porque, como já advertia a sabedoria retórica antiga, embora sem as ilações da ética de Aristóteles, o grande perigo do pathos é o exagero, é transformar a indignação ou a compaixão em afetação. Isso torna o pathos vazio, exagerado ("profundo"), torna-o bathos

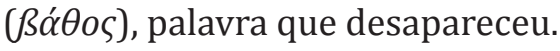


A ligação entre pathos e ethos, em Aristóteles, está no contexto de considerá-las formas de persuasão retórica, ao lado do logos, como dito. E os raciocínios demonstrativos do logos não tinham o prestígio que a ciência "lógica" lhes veio emprestar na modernidade. Há uma consciência clara, já na Grécia antiga, de que certos assuntos humanos, assim como determinados tipos de auditório, pouco têm a fazer com a razão "lógica". Mesmo assim, essa razão analítica, tal como entendida hoje, de caráter "racionalmente" cogente, constituía apenas um dos aspectos da palavra.

O termo logos, plural lógoi, passou a ser traduzido como "razão" ou "ciência", mas originalmente parece ter significado "linguagem". O primeiro sentido de logos - na forma verbal légein - é falar, dizer, designando a princípio apenas o próprio ato, mas depois também o resultado da ação, ou seja, a fala mesma. A segunda conotação adquirida pela palavra é a de reunir, colecionar, como em katálogos. Esses sentidos permanecem ligados à palavra logos desde seu aparecimento, assim como os de razão, argumentação, definição, pensamento, verbo, oração etc., muitos deles com frequente emprego na retórica (UEDING, 1994, p. 624 s.).

O sentido de logos guarda alguma oposição com o de érgon, que significa resultado, efeito, efetividade, realidade. Essa distinção é trazida a princípio por Anaxágoras e depois os sofistas a fazem equivaler àquela entre nomos (logos) e physis, (érgon), emprestando assim um caráter normativo ao logos. Só depois surge a acepção atual de "lógica", mas fica competindo com vários outros sentidos durante longo tempo. A diferença do sentido atual em relação às origens gregas fica clara quando se observa que o estudo metódico do pensamento racional-dedutivo é chamado por Aristóteles de analítica e não de lógica, pois esta última expressão é utilizada para a arte da disputa argumentativa; para o filósofo, é a analítica e não a lógica que se opõe à retórica. Na mesma direção, sofistas como Isócrates definiam a retórica como a arte do logos.

Em outras palavras, logos é linguagem em sentido performático, com todas as suas estratégias e matizes, não designa apenas o sistema de regras dirigentes do pensamento. Por isso o sofista Protágoras defende o dissoi logoi e afirma que, em qualquer tema, é possível manter posições (logoi) contrárias (dissoi). Daí porque o homem é a medida de todas as coisas, as quais podem ser consideradas, ao mesmo tempo, boas e más, 
justas e injustas, verdadeiras e falsas. Não há uma separação nítida entre o logos lógico da "razão" e os âmbitos da opinião, da percepção ou do mito. Esse é o logos da retórica, uma das vias da persuasão.

\section{OUTRAS VIAS RETÓRICAS E A FALÁCIA DE UMA RETÓRICA NORMATIVA}

$\mathrm{Na}$ literatura grega antiga que chegou até hoje e assim moldou a cultura ocidental, Aristóteles parece ter sido o primeiro a escrever sobre retórica sem o objetivo direto de ensinar habilidades ou estratégias discursivas. Por isso é considerado o criador da retórica analítica ou "científica” (SCHLIEFFEN, 2006, p. 42-64). Uma das teses da retórica realista, como dito, considera a retórica de Aristóteles normativa, ou seja, ele quer mais prescrever como o discurso deve ser (ethos, pathos e logos) do que descrever como ele efetivamente ocorre. Por isso sua retórica não pode ser considerada analítica, não é empírica. 0 estudo de vias outras para obter assentimento ou imposição de opinião a partir do discurso, que não a persuasão, não tem necessariamente o objetivo antiético, imaginado por Aristóteles, para enganar os outros e vencer a todo custo; mostra também como evitar ser enganado e vencido a todo custo, por exemplo. Daí que é até trivial entre os estudiosos a afirmação de que as estratégias retóricas, quaisquer que sejam, são menos eficazes diante de quem conhece retórica (LAUSBERG, 2004, p. 77). Isso porque as estratégias dos retóricos utilizam exatamente os preconceitos do senso comum sobre a suposta evidência da realidade para obter os efeitos desejados.

A postura analítica da retórica realista procura ser eticamente neutra e assim afasta-se das concepções normativas, que concentram o estudo do discurso exclusivamente no consenso, na cooperação, na persuasão ou no afeto. Se é certo que a persuasão faz parte dos discursos humanos, muitas outras estratégias precisam ser estudadas, sobretudo se o interesse é compreender o direito e a retórica jurídica.

Essas estratégias para a narrativa vitoriosa que vai constituir a realidade da retórica material são várias. Observem-se agora algumas delas, claro que numa relação apenas exemplificativa. Nunca é demais relembrar os tipos ideais: essas estratégias, assim como as persuasivas 
de Aristóteles (logos, ethos e pathos) e quaisquer outras, não se separam claramente, interpenetram-se nos eventos reais.

A persuasão sincera pode ser a via retórica mais importante, por sua eficácia e permanência no tempo, pela força do acordo etc., mas não é absolutamente a única e um estudo realista da retórica precisa se ocupar também de sedução, ironia, engodo, mentira, simulação, dissimulação, ameaça, blefe, de todas as estratégias, em suma, presentes na comunicação humana e reveladas pelos sofistas, estudadas por figuras de retórica como anfibolias, antonomasias, aporias, apócrises, catacreses, hipérboles, lítotes etc.

Começando por uma característica muito importante no direito, considerada por muitos autores sua diferença específica em relação aos outros tipos de normas, uma via retórica fundamental é a ameaça de violência, tradicionalmente chamada coercitividade ou coercibilidade. Ressalte-se que a violência efetiva é evento, não é linguagem, logo não faz parte da retórica. Mas ameaça é comunicação, tem que ser compreendida pelo emissor e pelo receptor; ela não é irresistível como a violência efetiva, pois pode ser enfrentada pelo risco, que é comunicacional, ou seja, retórico.

Claro que há limites à eficácia dessa coercitividade e que a persuasão constitui uma comunicação mais eficiente, daí o idealismo normativo de Arendt e Alexy. Todo direito quer ter, ao lado da ameaça de coação, a pretensão de persuadir, é o que Alexy chama a pretensão à "correção" ou à "justiça". 0 direito pode, por exemplo, obrigar o pai a pagar a pensão alimentícia, mas jamais a amar o filho.

Ameaça de violência significa força, no sentido de uma capacidade de provocar consequência desejável ou indesejável para alguém, uma possibilidade de violência que de modo algum tem caráter necessariamente físico. A força introduz, para o código do poder, um esquema binário: o forte e o fraco. Não há, obviamente, uma relação automática e direta entre direito/não-direito, força/fraqueza, ainda que a identificação seja sempre tentadora (justiça é a vontade do mais forte, disse Trasímaco). Uma teoria do poder e do direito, com base somente na força ou na ameaça, é também demasiadamente simplista, mas isso não significa que se possa excluí-las dos estudos retóricos. Daí o grande número de defensores da ideia de que a violência é um componente que não pode ser ignorado no 
estudo das relações humanas, seja de perspectiva política ou psicológica (SOREL, 1919, p. 81 s.; VILLAFAÑE, 1973, p. 75; FINER e SELINGER, 1975, p. 48; STOHL e MELO, 1976, p. 25).

Uma das funções do direito é justamente a racionalização da violência pela comunicação clara da força, saber quem a detém e de onde a violência pode vir a emanar. Deixada em seu curso natural, a violência é um componente ineludível da natureza humana e em seu estado bruto sequer conhece limites, como se pode observar nos arroubos sádicos que a história exibe a todo tempo e lugar. Em suma, a violência precisa ser racionalizada pela retórica do direito e a coercitividade é um instrumento desse processo. 0 poder, é verdade, não se apoia apenas na ameaça de violência, mas também no prestígio, no conhecimento, na lealdade. Um dado, porém, não pode ser ignorado: à medida que a complexidade social aumenta e as demais ordens éticas, como a moral e a religião, se pulverizam, a ameaça de violência tende a se sobrepor aos outros componentes do poder. Mas o controle da violência acarreta sua ameaça potencial e não seu emprego efetivo. Sem essa ameaça, contudo, o prestígio (do ethos), o conhecimento (do logos) e a lealdade (do pathos) não são suficientes para garantir o direito.

Na tradição retórica, a simulação e a dissimulação são espécies de ironia e sempre aparecem estreitamente ligadas, até mesmo complementares, embora diferenciadas pela relação entre a mensagem emitida e a intenção do autor. No mundo moderno as três estratégias de conduta consolidaram suas diferenças. A simulação ocorre quando o orador afirma algo em que ele mesmo não acredita, quer aparentar que há algo que não há; a dissimulação, ao contrário, procura esconder ou negar algo em que o orador acredita, quer aparentar que não existe algo que existe. Na ironia, o destinatário da mensagem precisa percebê-la de alguma maneira, mas sem conhecer as reais intenções do orador, porque senão se trata de mentira pura e simples e não de ironia. A estratégia é que o emissor da mensagem não quer tornar conhecida sua própria posição, pois considera que assim enfraquecerá sua estratégia discursiva (LAUSBERG, 2004, p. 251-254; PARINI, 2013, p. 305 s.).

A mentira, outra via retórica, consiste na faculdade de não cumprir promessas, pois, mesmo quando se refere a eventos passados, tem 
função de obter vantagem no futuro. 0 conceito é por vezes ampliado para além das relações humanas, quando se fala também em "mentira" biológica: "mesmo fora do mundo animal, onde quer que seja necessário lutar pela existência, impera, de forma absoluta, uma lei: o engano, a fraude." Quanto à mentira humana (retórica), o autor vai levantar a hipótese de que as profissões criam "tipos especiais" de mentirosos, e analisa psiquiatricamente a mentira como um gênero que contém espécies, numa espécie de profissionalização da mentira ou, pelo menos, dos tipos antropológicos de mentirosos:

A caça, o turismo, a vida militar, criaram a figura característica do gabarola; a religião, a política e a diplomacia, a do hipócrita; a medicina deu-nos a figura do charlatão e o comércio o tipo do burlão (BATTISTELLI, 1945, p. 21).

Também em Hannah Arendt, a faculdade (política) de agir, que gera a mais digna atividade que o ser humano pode desempenhar, e a capacidade para mentir são consideradas atributos humanos estreitamente conexos, pois ambas modificam a realidade, têm essa liberdade. É na liberdade de agir sobre o mundo que a mentira se assemelha à política e ao direito, pois a mentira é uma forma de ação porque ambas dependem da liberdade. Para ter sucesso como estratégia retórica, a mentira precisa parecer plausível, ou seja, precisa estar associada a uma crença na verdade, na medida em que são conceitos correlatos e um se converte em parâmetro do outro: a mentira precisa parecer verdadeira para funcionar.

Assim como o senso comum, essas visões filosóficas dominantes pressupõem posse da "verdade" por parte daquele que define determinado discurso como "mentira".

Na época contemporânea, a importância da mentira cresceu com o aumento e a sofisticação dos meios de comunicação: opiniões, boatos anônimos e exposição da intimidade passaram a interferir muito mais sobre o uso público da linguagem e a formação da "verdade factual". A internet, com seus infinitos aplicações e aplicativos, trouxe tecnologias que superaram os limites localizados das intrigas palacianas, a que a tradicional mentira política se vira restrita antes, e as fronteiras entre o público e o privado desapareceram. 
Aqui um ponto importante: falar em mentira, de um ponto de vista retórico realista não pressupõe conviç̧ão sobre verdade objetiva, como no argumento a contrario sensu utilizado contra os céticos (a afirmação "a verdade não existe" seria apresentada pelos céticos como "verdadeira", assim contradizendo a si mesma), vez que o interesse analítico é somente descrever como as pessoas utilizam esses conceitos. E mesmo no nível estratégico, o mentiroso não tem que necessariamente saber a verdade ou crer nela para poder mentir. Nesse sentido de oposição à verdade, a mentira não existe, consiste apenas em uma palavra mais genérica e imprecisa para designar diferentes caminhos da retórica.

Um modo para escapar ao problema é diferençar "mentira" de "insinceridade", palavra que não pressupõe oposição a "verdade", mas sim a "crença", e a crença, ao contrário da verdade, é um fenômeno facilmente perceptível.

Aí se pode definir a mentira como uma sentença dita por alguém que nela não acredita, mas espera que os ouvintes o façam. Se o orador acredita no que diz, e isso se revela "falso", não se trata de mentira, mas de erro. Quando o próprio orador não acredita no que está dizendo, mas isso é claro aos olhos de outros, não se trata de mentira, mas de ironia.

Eticamente, a mentira tem sido frequentemente considerada má e algumas religiões a consideram pecado; é um problema de ética prática (estratégica) determinar se toda mentira é má ou se há ocasiões em que não, determinar quais os limites da obrigação moral de informar todos sobre tudo ou quem sobre o que. No direito hodierno a mentira assume posição de grande importância e sua utilização é óbvia: ninguém acredita no que é dito num processo judicial, sabe-se que haverá mentiras e a lei nas democracias até as protege (não se pode ser constrangido a dizer algo que vá provocar prejuízo próprio), embora ameace punir o falso testemunho.

$\mathrm{Na}$ ética da etiqueta, a hipocrisia não é apenas aceita, mas recomendada em certas circunstâncias, como na assim chamada "mentira social", ou seja, casos de diplomacia do cotidiano, dizer que tudo está bem, evitar sinceridade ofensiva ou que vá causar tristeza e assim por diante. Essa forma de discurso constitui uma das espécies da mentira e os dois conceitos só podem ser distinguidos no caso concreto, pois consiste em parecer ou fingir acreditar em algo que não se é ou em que 
não se acredita. Por isso mesmo, o uso comum confunde hipocrisia com simulação, dissimulação, fraude etc.

0 engodo também pode se confundir com mentira ou hipocrisia, pois leva a uma conclusão indesejada, inadequada, prejudicial da parte do receptor da mensagem, isto é, o orador quer enganar o ouvinte. Porém o engodo retórico tem um sentido próprio na medida em que a metáfora que o origina é formada a partir da ideia de isca, como utilizada na pesca: o orador oferece algo desejável para a audiência, aproveita-se de interesses dos ouvintes, embora com caráter deliberadamente falso e que depois será prejudicial a eles ou vantajoso para o orador ou ambos os efeitos. Consiste de um atrativo para encantar a partir de fraquezas e aspirações alheias.

Noutro sentido vão os diversos níveis de gabarolice, arrogância, soberba, empáfia (ou impáfia). Na Ética a Nicômaco, Aristóteles (1993, 1127a13 e s., p. 374 s.) procura diferençar a gabarolice ou bazófia ( $\alpha ́ \lambda \alpha \zeta o v \epsilon i ́ \alpha$, ala-

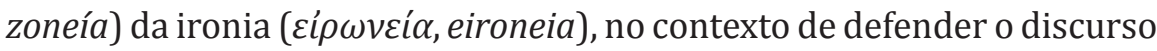
socrático como irônico, mas não arrogante ou soberbo, na medida em que a ironia seria eticamente menos reprovável. Não se deve esquecer o horizonte do discurso de Aristóteles, que tem sempre a verdade como possibilidade indiscutível e desiderato a ser atingido, ao examinar as diferenças presentes no caráter dos seres humanos.

O blefe é outra das estratégias sofísticas das relações humanas. A expressão parece ter-se originado do jogo de cartas, daí passando a qualquer ato de fingir ter determinados recursos, exagerar falsamente as próprias capacidades, aproveitando-se da insegurança ou do receio do receptor da mensagem. Analisando seu emprego retórico tem-se: 1 . Simular ter poder para obtenção de algum resultado, normalmente apostando alto, com a intenção de ludibriar os demais participantes para desistirem de assumir quaisquer riscos, fazendo com que abandonem naquele momento uma disputa que poderiam eventualmente vencer. 2 . Induzir alguém a pensar que a afirmação sobre determinada capacidade é sincera, quando não o é, fazer parecer que alguma coisa é melhor para os circunstantes do que eles efetivamente achariam sem o blefe. 3 . Dizer que se pretende fazer alguma coisa que já de antemão não se pretende fazer.

A sedução, conceito hoje próximo dos de carisma, fascínio, magnetismo, ressalta um conjunto de características que despertam em outrem 
interesse, desejo, simpatia. A princípio ligada ao pathos, a sedução vai adquirindo um tom negativo na ética e na retórica estoica e cristã, como paixão que deve ser superada pelo logos da reta razão (HORA, 2014, p. 89 s.), adquirindo a pouco e pouco um sentido de procedimento (ação) ou faculdade de atrair alguém de forma ardilosa ou enganosa mediante apelo a suas expectativas, fraquezas, desejos, num processo de perverte e corromper. Pode assim assemelhar-se ao engodo. Mas este não é o sentido originário nem intrínseco da palavra, submetida a opções éticas vitoriosas das igrejas do cristianismo.

A chamada falsa modéstia é outra estratégia retórica de larga utilização, que lança mão do habitual sucesso de estratégia oposta, qual seja, a humildade ou modéstia sincera. 0 emissor ou receptor da mensagem tenta aparentar desmerecimento, ao mesmo tempo em que se considera digno de todos os elogios. Seguindo a verve cortante de Schopenhauer (1917), a diferença está nas habilidades desiguais: a modéstia equivale a mera honestidade, quando exprimida por pessoas limitadas; nos seres humanos talentosos, não passa de hipocrisia. A diferença é que a falsa modéstia envolve necessariamente uma autoavaliação, enquanto a hipocrisia diz respeito a uma gama mais ampla de eventos.

\section{CONCLUSÃO: FILOSOFIA DA CONSCIÊNCIA, ATIVISMO JUDICIAL E CONTROLE PÚBLICO DA LINGUAGEM}

Ressalte-se que enxergar a realidade humana como um fenômeno retórico, relato dominante em cuja constituição o direito em geral e a decisão jurídica em particular têm peso notável, não implica defender que o decididor do caso é livre de constrangimentos e afirmar um ativismo judiciário nos termos de seguir a - obviamente própria - "consciência".

Já se disse o suficiente aqui sobre o controle público da linguagem. Trasladando-o para o campo do direito, contudo, a sugestão é que o Brasil precisa de mais ênfase na doutrina como participante do processo de constituição da realidade jurídica - o relato dominante -, fazer em fonte do direito as opiniões daqueles que o conhecem, os doutos e docentes - ambas as palavras oriundas da raiz docere - como forma de combater 
o casuísmo irracionalista e a imprevisibilidade que têm caracterizado a atividade daqueles que decidem questões de direito, os quais, no mundo de hoje, vão muito além dos juízes.

Além de os sistemas legislativos e legisladores em geral virem perdendo poder e se terem mostrado ineficientes para enfrentar a sociedade complexa contemporânea, na qual aumentam a ambiguidade e a vagueza das visões de mundo e consequentemente das interpretações das leis, o poder legislativo brasileiro reflete outras mazelas sociais específicas. Dentre outras, evita decidir sobre temas importantes, porque assim consegue congraçar mais eleitores, por sua vez ignorantes, inconscientes ou desinteressados das opiniões de "seus representantes". Por isso não legisla sobre interrupção terapêutica do parto de feto mero-encefálico, pesquisas com células-tronco, até greve de funcionários públicos, nem união homoafetiva, apenas como exemplos. Seguindo a metáfora de Hannah Arendt (1972, p. 20), ao analisar o perfil do revolucionário, ninguém toma poder de ninguém. No caso brasileiro, o legislativo antes deixa o poder "largado na rua" (lying on the street) e daí o judiciário, o executivo, as agências reguladoras e outras instâncias as mais diversas o tomam e exercem.

Claro que o legislador mesmo poderia diminuir o casuísmo decisionista brasileiro, se se fizesse mais presente. Na falta de orientação legal, pois a lei supostamente deve balizar a atividade do magistrado, o poder judiciário se vê diariamente confrontado com o chamado "ativismo" (ou "protagonismo"), pois precisa decidir, mais cedo ou mais tarde, sobre temas importantes que o legislador deixa propositalmente em aberto. E não apenas os tribunais superiores; uma vez que vigora no Brasil o sistema do livre convencimento do juiz, que não pode ser constrangido a determinada orientação na interpretação da lei, o ativismo também se faz presente nas instâncias inferiores do judiciário brasileiro. Isso causa disfunções até na psique dos juízes, iludidos pela convicção de que efetivamente possuem "notório saber jurídico" e "reputação ilibada" (causando, em casos mais graves, a já proverbial "juizite"). Mais ainda, das decisões dos tribunais superiores não cabe recurso a outra instância, o que traz um problema permanente de legitimação para essas normas gerais criadas pelos tribunais superiores e, paradoxalmente, enfraquece $o$ 
próprio decisionismo judicial. Sem contar a insegurança gerada por juízes prontos a abusar de sua autoridade e de seu mediano saber empírico.

Mas tampouco se deve acreditar na necessidade ou sequer possibilidade de uma só decisão correta para cada conflito concreto, como se os relatos sobre os eventos pudessem ser uníssonos e a discricionariedade ou arbitrariedade dos atores pudesse ser eliminada por "respostas corretas" (Streck, 2009, p. 159 s.). Mais ainda, o debate brasileiro sobre se quem cria o direito é o legislativo ou o judiciário - que substituiu o debate sobre legislativo versus executivo no início da vigência da Constituição de 1988 e da proliferação de medidas provisórias - esquece que quem faz boa parte do direito hoje são funcionários públicos de terceiro escalão ou mesmo terceirizados que nem públicos são. Eles hoje fazem proliferar normas jurídicas por meio de instruções normativas do Banco Central, resoluções do Conselho Administrativo de Defesa Econômica ou Conselho Administrativo de Recursos Fiscais, regulamentos de diferentes aeroportos, Agência Nacional de Energia Elétrica ou de Telecomunicações. Isso faz do Brasil ótimo laboratório de análise retórica, mas não é funcional para o país. Talvez o juiz alemão se ache divino ou pense que pode fazer o que quiser da Constituição e da lei, mas não tem coragem de dizer isso, é fiscalizado de todos os lados, por associações civis, órgãos públicos, imprensa, doutrina etc.

Como dito, a retórica realista tentada aqui e em outros escritos não é objetivista, claro, mas tampouco subjetivista. Radicalmente, na raiz, defende que o controle público da linguagem cria o real. Se os únicos participantes desse controle são 11 funcionários públicos indicados pelo poder executivo, diante dos quais os demais poderes se curvaram em subserviência, lamentável. Aí o relato vencedor, a realidade jurídica será mesmo conceder habeas corpus com bases astrológicas, dizer que a Constituição nada diz, "nós" é que dizemos o que ela diz, ou que primeiro decido com base em minhas convicção e experiência, depois vou achar um fundamento no ordenamento jurídico. Típico de um direito primitivo, arremedo de dogmática jurídica, como o brasileiro. 


\section{REFERÊNCIAS}

ADEODATO, João Maurício (2012). A retórica constitucional - sobre tolerância, direitos humanos e outros fundamentos éticos do direito positivo. São Paulo: Saraiva, 2 a ed.

ARENDT, Hannah (1972). Thoughts on Politics and Revolution, in Crises of the Republic (Lying in Politics, Civil Disobedience, on Violence, Thoughts on Politics and Revolution), New York / London: Harvest /HBJ.

ARISTOTLE (1990a). Rhetoric. Trad. W. Rhys Roberts. Col. Great Books of the Western World. Chicago: Encyclopaedia Britannica, v. 8.

ARISTOTLE (1990b). Nichomachean Ethics. W. D. Ross. Col. Great Books of the Western World. Chicago: Encyclopaedia Britannica, 1990, v. 8.

BALLWEG, Ottmar (1989). Entwurf einer analytischen Rhetorik, in SCHANZE, Helmut (Hrsg.). Rhetorik und Philosophie. München: Wilhelm Fink.

BALLWEG, Ottmar (1982). Phronetik, Semiotic und Rhetorik, in: BALLWEG, Ottmar. Rhetorische Rechtstheorie - Theodor Viehweg zum 75. Geburtstag. München: Alber, p. 27-71.

BAILLY, Anatole (2000). Dictionnaire Grec Français (rédigé avec le concours de E. Egger). Paris: Hachette, 27e. ed.

BATTISTELLI, Luigi (1945). A mentira, trad. Fernando de Miranda. São Paulo: Saraiva.

BLUMENBERG, Hans (1986). Antropologische Annäherung an die Aktualität der Rhetorik. In: BLUMENBERG, Hans. Wirklichkeiten, in denen wir leben Aufsätze und eine Rede. Stuttgart: Philipp Reclam, p. 104-136.

CHAUÍ, Marilena (2001). Convite à filosofia. São Paulo: Ática.

FINER, Sam E.; SELINGER, Martin (1975). O papel político da violência, trad. Angela Arieira. Revista de Ciência Política, n. 18 (2). Rio de Janeiro: abr.-jun., p. 48-67.

GEHLEN, Arnold (1978). Der Mensch. Seine Natur und seine Stellung in der Welt. Wiesbaden: Akademische Verlagsgesellschaft.

HARTMANN, Nicolai (1946). Grundzüge einer Metaphysik der Erkenntnis. Berlin: Walter de Gruyter. 
HEGEL, Georg Wilhelm Friedrich (2000). Verhältnis des Skeptizismus zur Philosophie. Darstellung seiner verschiedenen Modifikationen und Vergleichung des neuesten mit dem alten. Aufsätze aus dem Kritischen Journal der Philosophie, in Philosophie von Platon bis Nietzsche (CD Rom). Berlin: Digitale Bibliothek, p. 38.312-38.401.

HORA, Graziela Bacchi (2014). Sedução e convencimento: revalorização do elemento retórico pathos como abertura de perspectiva para o tema da segurança jurídica. In: ADEODATO, João Maurício. A retórica de Aristóteles e o direito bases clássicas para um grupo de pesquisa em retórica jurídica. Curitiba: CAPES / FDV / CRV, p. 89-100.

LAUSBERG, Heinrich (2005/1967). Elemente der literarischen Rhetorik. München: Max Hueber Verlag, 3. durgesehene Auflage. Tradução portuguesa de R. M. Rosado Fernandes. Elementos de retórica literária. Lisboa: Fundação Calouste Gulbenkian, 5a. ed.

LIDDEL, Henry George e SCOTT, Robert (comp.) (1996). A Greek-English Lexicon. Oxford: Clarendon Press.

NERI, Demétrio (2004). Filosofia moral - manual introdutivo. Trad. Orlando Soares Moreira. São Paulo: Loyola.

NIETZSCHE, Friedrich (1922). Rhetorik. Darstellung der antiken Rhetorik; Vorlesung Sommer 1874, dreistündig. Gesammelte Werke. Band 5. München: Musarion Verlag.

O'SULLIVAN, Noel (1977). Hannah Arendt. A Nostalgia helênica e a sociedade industrial. Documentação e Atualidade Política, $\mathrm{n}^{0}$ 5. Brasília, out.-dez., p. 15-25.

PARINI, Pedro (2013). A metáfora do direito e a retórica da ironia no pensamento jurídico. Tese de Doutorado. Recife: UFPE.

PELLEGRIN, Pierre (2001). Le Vocabulaire d'Aristote. Paris: Ellipses.

SCHLIEFFEN, Katharina von (2006). Rhetorische Analyse des Rechts: Risiken, Gewinn und neue Einsichten, in: Rouven Soudry (Org.). Rhetorik. Eine interdisziplinäre Einführung in die rhetorische Praxis. Heidelberg: C. F. Müller, p. 42-64.

SCHOPENHAUER, Arthur (1917). Aphorismen zur Lebensweisheit. Leipzig: Insel Verlag. 
SEXTUS EMPIRICUS (2013). Contra os retóricos (Pros Rhtoras). Edição bilíngue. Texto Integral. Tradução, apresentação e comentários de Rafael Huguenin e Rodrigo Pinto de Brito. São Paulo: UNESP.

SOREL, Georges (1919). Réflexions sur la violence. Paris: Marcel Rivière.

STOHL, Michael; MELO, José Luiz (1976). Teoria e método em estudos sobre a relação entre conflito e violência doméstica e externa, trad. Pedro Maligo e Eli de Fátima de Lima. Revista de Ciência Política, n. 19 (1). Rio de Janeiro: jan.mar., p. 25-59.

STRECK, Lenio (2010). 0 que é isto - Decido conforme minha consciência? Porto Alegre: Livraria do Advogado.

UEDING, Gert (Hrsg.) (1994). Historisches Wörterbuch der Rhetorik, Band 5. Darmstadt: Wissenschaftliche Buchgesellschaft.

VILLAFAÑE, Emilio Serrano (1973). La violencia y el odio y su papel en la politica del mundo actual, in: Diversos Autores. El odio en el mundo actual. Madrid: Alianza Editorial, p. 75-105.

WEBER, Max (1985). Wirtschaft und Gesellschaft - Grundriss der verstehenden Soziologie. Tübingen: J. C. B. Mohr/Paul Siebeck.

Recebido em: 19-4-2017

Autor convidado

\section{João Maurício Adeodato}

Livre-Docente e Doutor pela Faculdade de Direito da Universidade de São Paulo. Pós-Doutor e Professor Convidado pela Fundação Humboldt. Professor da Faculdade de Direito de Vitória e da Faculdade Damas. Coordenador dos Cursos de Direito do Grupo Ser Educacional. Ex-Professor Titular da Faculdade de Direito do Recife. Pesquisador 1-A do CNPq. Currículo completo em: http://lattes.cnpq.br/8269423647045727). E-mail:

Faculdade de Direito de Vitória. Programa de Pós-Graduação em Direitos e Garantias Fundamentais.

Rua Juiz Alexandre Martins de Castro Filho, 215. Santa Lúcia. Vitória - ES. CEP 29056-295. 